\title{
AGE-SPECIFIC DEATH RATES IN NEGRO INFANTS AND YOUNG CHILDREN IN ANTIGUA, BRITISH WEST INDIES, IN RECENT YEARS
}

\author{
BY \\ K. H. UTTLEY \\ Medical Department, St. John's, Antigua, West Indies
}

A description of the environmental conditions, demography, and social structure of the Negro population of Antigua has already been presented (Uttley, 1960, 1961a, b,); these matters need not therefore be recapitulated here.

\section{TABLE I}

MORTALITY IN INFANCY AND EARLY CHILDHOOD ANTIGUA, 1955-63, AND ENGLAND AND WALES, 1959

\begin{tabular}{|c|c|c|c|c|}
\hline \multicolumn{2}{|c|}{ Mortality Rate } & \multirow{2}{*}{$\begin{array}{c}\begin{array}{c}\text { Antigua } \\
(1955-63)\end{array} \\
20 \cdot 1 \\
7 \cdot 0 \\
10 \cdot 8 \\
13 \cdot 4 \\
9 \cdot 6\end{array}$} & \multirow{2}{*}{$\begin{array}{c}\begin{array}{c}\text { England and } \\
\text { Wales } \\
(1959)^{*}\end{array} \\
15.9 \\
2.4 \\
2.1 \\
1.8\end{array}$} & \multirow{2}{*}{$\begin{array}{c}\begin{array}{c}\text { Antigua } \\
\text { England and } \\
\text { Wales }\end{array} \\
1 \cdot 3 \\
2.9 \\
5 \cdot 1 \\
12.4\end{array}$} \\
\hline $\begin{array}{l}\text { Per } 1,000 \\
\text { Livebirths } \\
\text { at Age } \\
\text { Specified } \\
\text { (mths) }\end{array}$ & $\begin{array}{l}\text { Under } 1 \\
1-2 \\
3-5 \\
6-8 \\
9-11\end{array}$ & & & \\
\hline & $\begin{array}{l}\text { Total } \\
\text { under } \\
1 \text { Year }\end{array}$ & 60.9 & $22 \cdot 2$ & $2 \cdot 8$ \\
\hline $\begin{array}{l}\text { Per 1,000 } \\
\text { Living at } \\
\text { Age Speci- } \\
\text { fied (yrs) }\end{array}$ & $\begin{array}{l}1-2 \\
2-3 \\
3-4 \\
4-5\end{array}$ & $\begin{array}{r}22 \cdot 9 \\
3 \cdot 7 \\
1 \cdot 8 \\
0 \cdot 7\end{array}$ & $\begin{array}{l}1.44 \\
0.87 \\
0.71 \\
0.56\end{array}$ & $\begin{array}{r}15 \cdot 9 \\
4 \cdot 2 \\
2 \cdot 5 \\
1 \cdot 2\end{array}$ \\
\hline
\end{tabular}

* See CMO's Report to the Ministry of Health (1960).
Table I shows the death rate per 1,000 live births for infants aged under one year, and the death rates per 1,000 living for those between 1 and 5 years of age for the years 1955 to 1963 , with the corresponding figures for England and Wales for 1959.

The Table shows that in Antigua the neonatal mortality is moderately high. The figure is lower at 1 to 2 months of age but rises again at 3 to 5 months. One would have expected a further rise when weaning takes place at the ninth month, but this does not occur, and there is in fact a fall (note the similar drop observed in Barbados, Table II). The rate continues high throughout the second year of life, when the Colony's death returns show that broncho-pneumonia and gastro-enteritis are the main killing diseases. After the second year a marked fall begins and this continues to the end of the fifth year, when the figure falls below 1 per 1,000 living.

Antiguan neonatal mortality is about one-third higher than that in England and Wales. The ratio thereafter rises rapidly until towards the end of the first year the Antiguan figure is over twelve times as

TABLE II

MORTALITY PER 1,000 LIVEBIRTHS, AND PER 1,000 LIVING AT AGES UNDER 5 YEARS, IN CERTAIN BRITISH CARIBBEAN ISLANDS

\begin{tabular}{|c|c|c|c|c|c|c|c|c|}
\hline \multirow{2}{*}{ Caribbean Islands } & \multirow{2}{*}{$\cdots$} & \multirow[b]{2}{*}{$\cdots$} & \multirow{2}{*}{$\cdots$} & \multicolumn{2}{|c|}{ Leeward Islands } & \multicolumn{2}{|c|}{ Windward Islands } & \multirow{2}{*}{$\frac{\text { Barbados }}{\text { Barbados* }}$} \\
\hline & & & & St. Kitts* & Antigua & Grenada* & St. Vincent $†$ & \\
\hline $\begin{array}{l}\text { Total Population } \\
\text { Date } \quad . \quad \quad \ldots\end{array}$ & $\because$ & $\because$. & $\because$ & $\begin{array}{r}56,000 \\
1960-62\end{array}$ & $\begin{array}{r}55,000 \\
1961-63\end{array}$ & $\begin{array}{r}89,000 \\
1961-62\end{array}$ & $\begin{array}{r}82,000 \\
1960-62\end{array}$ & $\begin{array}{r}235,000 \\
1960-62\end{array}$ \\
\hline \multirow[t]{2}{*}{$\begin{array}{l}\text { Mortality per } 1,000 \\
\text { Livebirths at } \\
\text { Age Specified (mths) }\end{array}$} & & \multicolumn{2}{|c|}{$\begin{array}{c}\text { Under } 1 \\
1-2 \\
3-5 \\
6-8 \\
9-11\end{array}$} & $\begin{array}{r}29 \cdot 7 \\
4 \cdot 9 \\
19 \cdot 4 \\
18 \cdot 8 \\
18 \cdot 3\end{array}$ & $\begin{array}{r}19 \cdot 1 \\
5 \cdot 0 \\
8 \cdot 1 \\
11 \cdot 0 \\
7 \cdot 2\end{array}$ & $\begin{array}{r}15 \cdot 4 \\
4 \cdot 7 \\
10 \cdot 3 \\
15 \cdot 4 \\
19 \cdot 2\end{array}$ & & $\begin{array}{r}31 \cdot 0 \\
10.0 \\
11.7 \\
9.2 \\
6.0\end{array}$ \\
\hline & & \multicolumn{2}{|c|}{ Total under 1 Year } & $91 \cdot 1$ & $50 \cdot 4$ & $65 \cdot 0$ & $110 \cdot 3$ & $67 \cdot 9$ \\
\hline $\begin{array}{l}\text { Mortality per } 1,000 \\
\text { Living at Age } \\
\text { Specified (yrs) }\end{array}$ & & & $\begin{array}{l}1-2 \\
2-3 \\
3-4 \\
4-5\end{array}$ & $\begin{array}{r}35 \cdot 9 \\
7 \cdot 9 \\
2 \cdot 2 \\
2 \cdot 4\end{array}$ & $\begin{array}{r}21 \cdot 1 \\
3 \cdot 2 \\
2 \cdot 8 \\
0.8\end{array}$ & $\begin{array}{r}33 \\
7 \\
3 \\
1\end{array}$ & $\begin{array}{r}147.6 \\
25.3 \\
7.6 \\
3.6\end{array}$ & $\begin{array}{l}8 \cdot 7 \\
3 \cdot 1 \\
1 \cdot 4 \\
1 \cdot 1\end{array}$ \\
\hline
\end{tabular}

- See Boyd (1963) 
high; taking the first year as a whole, however, the Antiguan death rate is $\mathbf{2 . 8}$ times that in England and Wales.

In the second year of life, mortality in Antigua is nearly sixteen times as high as that in England and Wales, but once the child is firmly established as a toddler, the ratio falls rapidly, and mortality rates in the two countries are closely similar by the end of the fifth year of age.

The explanation of the high rates in Antigua is much the same as that for most tropical countries: poor environmental hygiene; lack of parental interest in clean food or clean infants; the frequent absence of the mother, who leaves the child with a grandmother or a sister while she is earning the family's living in the fields or elsewhere; unsuitable feeding with excessive amounts of carbohydrate food, poor in protein, both before and after weaning; a prevalence of gastro-enteritis and broncho-pneumonia, especially in the many drought years. These two diseases are serious health hazards because of the underlying, though subclinical, malnutrition that frequently prevails (Uttley, 1963). Overcrowding is fortunately not a problem because most houses have enough space around them, and the families live out of doors during daylight hours. In addition to this, the single town and all the villages of the Island have a supply of good piped water available at numerous standpipes.

One can infer from these figures that a great improvement in the neonatal death rate is unlikely to occur before a major decline in the rate for England and Wales, but that there is room for very great improvement throughout infancy and early childhood, especially from the sixth to the eighteenth month of life.

A comparison of the rates for Antigua for the last 3 or 4 years with those of certain neighbouring British Caribbean islands (Table II) shows that in general the data for Antigua compare very favourably with those of its neighbours. If we exclude the low neonatal death rate recorded for Grenada, which one suspects to be due to under-registration of deaths at this age in that island, the differences are mainly those of degree, the variations reflecting the lack to a greater or lesser degree of good environmental hygiene. Otherwise, living conditions are much the same in all the islands, though there is a higher standard of living in Antigua and Barbados. The exceptionally high figures for St. Vincent confirm the visitor's impression that living conditions are much more primitive there than elsewhere.

When the Caribbean figures are compared with those for England and Wales, the contrast shows what a long way these islands have to go before their environmental hygiene and vital statistics approach those of more advanced countries.

\section{SUMmaRY}

The age-specific death rates for Negro infants and young children in Antigua, British West Indies, have been calculated for the years 1955 to 1963 . They are compared with similar rates for other small islands in the eastern Caribbean and with those for England and Wales for 1959.

The overall Antiguan mortality of infants under one year of age is only 2.8 times greater than that for England and Wales, but during the last 3 months of that period it is as much as twelve times greater and at 1 to 2 years of age it is nearly sixteen times greater than in England and Wales; however, the figures fall and become comparable by the end of the fifth year of age.

\section{REFERENCES}

Boyd, P. I. (1963). Data collated from the annual reports of the Colonies concerned for a WHO/PASB seminar in Kingston, Jamaica.

Ministry of Health (1960). "C.M.O's Report for the Year 1959. Part II. On the State of the Public Health". HMSO, London.

Smart, G. B. (1964). Personal communication.

Uttley, K. H. (1960). Brit. J. prev. soc. Med., 14, 185.

— (1961a). Trans. roy. Soc. trop. Med. Hyg., 55, 69. (1961b). Tubercle (Lond.), 42, 444.

- (1963). Trans. roy. Soc. trop. Med. Hyg., 57, 41. 